\title{
Improving the distribution of FDI benefits: The need for policy-oriented research, advice, and advocacy
}

\author{
Karl P. Sauvant \\ Columbia Center on Sustainable Investment, \\ Columbia University, New York, NY 10027, USA \\ Correspondence: \\ KP Sauvant, Columbia Center on Sustainable \\ Investment, Columbia University, New York, \\ NY 10027, USA \\ e-mail: karlsauvant@gmail.com
}

\begin{abstract}
This article explores the different ways in which governments can increase the benefits of FDI and manage the relationship between governments and international investors in a mutually beneficial manner. It focusses on three concrete policy fields in which discussions are afoot that bear on this issue, and where opportunities to exercise influence exist: encouraging more sustainable FDI; enhancing the distribution of benefits associated with FDI; and anchoring sustainable FDI, corporate social responsibility, and responsible business conduct in the international investment law and policy regime and, specifically, in the context of the negotiations of an Investment Facilitation Framework for Development at the WTO. These are examples of policy areas that warrant attention, with a view toward scholars seeking to influence the way in which they are tackled, through applied multidisciplinary policyoriented research, concrete recommendations, and targeted advocacy.

Journal of International Business Policy (2021) 4, 244-26l.

https://doi.org/ 10.1057/s42214-021-00109-6
\end{abstract}

Keywords: FDI policies; sustainable FDI; CSR; international investment agreements; FDI costs and benefits; economic growth and development; linkages; investment facilitation

\section{INTRODUCTION}

In his article in the present issue of JIBP, Zhan (2021) outlines five major forces that are changing the foreign direct investment (FDI) landscape: economic governance realignment, the new industrial revolution, the sustainability endeavor, corporate accountability, and resilience-oriented restructuring. Each of these forces influences the relationship between governments and multinational enterprises (MNEs), as commented upon by Buckley (2021) from the perspective of theory, and elaborated by Srinivasan and Eden (2021) for digital MNEs.

The present article focuses on aspects of two of these forces, namely the sustainability endeavor and corporate accountability. It seeks to operationalize them in the context of the overarching question of the distribution of the benefits associated with FDI. This is a fundamental issue because, if governments' assessment of the economic impact of FDI - accentuated by non-economic considerations - is unfavorable, it is likely to lead to a deterioration
Received: 14 January 2021

Revised: 15 March 2021

Accepted: 17 March 2021

Online publication date: 12 May 2021 
of the relationship between international investors and governments. Hence, managing the relationship between governments and international investors depends on balancing the interests of these two actors.

I discuss this question from the perspective of governments and how governments can increase the benefits they derive from FDI. It is an effort that requires appropriate government policies (and appropriate corporate strategies), which, in turn, are informed by an assessment of the benefits that firms and governments derive from FDI. As one eminent economist put it: "[FDI] is as good or as bad as your own policies" (Bhagwati, 2021: 178).

Looking at FDI from the perspective of benefits for governments is important as scholars in international business have often assumed that FDI, in and of itself, is an effective means of promoting economic development. Indeed, the consensus is that, on balance, FDI can make a contribution to development; and while investment (including FDI) is not everything, everything is nothing without investment. Countries' welcoming policies toward FDI, and their competition to attract it, bear this out.

However, this is not necessarily always so and, in any event, other considerations can come into play when countries set policies. It appears that the welcoming approach of national policies ${ }^{1}$ is fracturing. Home countries fear job losses and increasingly seek to re-shore investment. Host countries, both developed and developing, are screening investment in light of national security interests. The legitimate aspirations regarding sustainable development and human rights are prompting calls for regulation and responsible investment. More deeply, the focus on sovereignty in the 1970s is resurfacing under the guise of national security, in the broader context of growing skepticism about the benefits of globalization.

All this means that the policies toward FDI - the environment in which MNEs can operate - can and will change over time. They are the outcome of a struggle between two conflicting objectives, epitomized by James Carville's "It's the economy, stupid", credited with helping Bill Clinton win the 1992 US presidential campaign by focusing on economic considerations, and Dominic Cumming's "Take back control", credited with helping Boris Johnson win the 2016 Brexit referendum by focusing on political considerations. This tension reminds us, to refer to Vernon's seminal study, that we remain "In the Hurricane's Eye": "a quiet place, but one surrounded by turmoil" (Vernon, 1998: 9). In fact, "if the boundaries of the nationstate and of the multinational enterprise grow fuzzier and less determinate, there is reason to anticipate even higher levels of tensions between multinational enterprises and public authorities" (Vernon, 1998: 182).

If anything, MNEs have become more important since 1998: the stock of inward FDI had risen ninefold by 2019. For their part, governments have become more assertive by taking relatively more measures that make the FDI investment climate less attractive. Hence, any concerns need to be addressed in ways that improve - and do not set back - the progress toward mutually beneficial national and international investment regimes that benefit both countries and international investors. This is all the more important if, indeed, "in a post pandemic world, there will be an even greater need and utility for globalization" (Contractor, 2021: 2$3)$, with MNEs as the most visible face of this process.

We need to take on that challenge. It requires clarifying the underlying issues and, where possible, seeking to influence the way in which they are addressed through applied policy-oriented research, policy advice, and policy advocacy. This requires research that is both accessible to policy makers and suggests specific courses of action to arrive at win-win outcomes that are seen as such by all.

Accordingly - and after having briefly discussed political considerations bearing on FDI policies this article focuses on three concrete policy fields in which discussions are afoot that bear on the distribution of benefits between MNEs and countries and where opportunities to exercise influence exist: encouraging more sustainable FDI; enhancing the distribution of benefits associated with FDI (exemplified for state contracts, transfer pricing, linkages, outward FDI); and anchoring sustainable FDI, corporate social responsibility (CSR) and responsible business conduct ${ }^{2}$ (an area in which MNEs can also act without legal requirements) in the international investment law and policy regime and, specifically, in the context of the negotiations of an Investment Facilitation Framework for Development in the World Trade Organization (WTO). These are examples of policy areas that warrant attention, with a view toward scholars seeking to influence the way in which they are tackled, through applied multidisciplinary policy-oriented 
research, concrete recommendations, and targeted advocacy.

\section{THE POLITICS OF FDI POLICIES}

Balancing the interests of governments and international investors is a vexed issue, as it requires managing a basic tension that underlies the objectives of both actors: MNEs undertake FDI to maintain or strengthen their competitiveness by obtaining better access to markets and resources, and they seek to do so in an international context; thus, e.g., a production facility may be transferred from a high-wage country to a low-wage country, or profits may be shifted from a high-tax country to tax havens. Governments, for their part, attract FDI as a tool to advance their economic growth and development, and they seek to do so in a national context; thus, e.g., they want that production is expanded in their economies and taxes paid in their jurisdictions. The challenge, therefore, is to find ways to reconcile MNEs' and governments' interests with each other, i.e., to arrive at an overlap - and balance - that makes it worthwhile for governments to admit FDI into their economies and for investors to invest in these economies. ${ }^{3}$

For most practical purposes, the reconciliation of corporate and governmental interests plays itself out first and foremost in the economic arena. At the same time, we need to keep in mind that, even if economic and efficiency considerations are favorable for countries, non-economic considerations may determine policy outcomes - and they may become even more important if and when the economic impact is limited or not clearly visible.

Also, non-economic considerations are becoming more important. ${ }^{4}$ The return to increased screening of incoming $\mathrm{FDI}^{5}$ is a case in point (although the absolute number of cases for which it takes place is quite small compared to the total number of new projects). As the United Nations Conference on Trade and Development (UNCTAD) (2021a: 1) reported for the period May-December 2020: "Fifty-two countries and the European Union (EU) took 96 investment policy measures in the review period (May 2020 to December 2020). Nearly half of these measures introduced new regulations or restrictions for investment - the highest ratio in almost two decades. Almost all new investment regulations or restrictions address national security concerns as more and more countries become worried that domestic core assets and technologies may fall prey to hostile foreign takeovers in the wake of the pandemic." Screening in light of legitimate public policy objectives is entirely understandable, as governments seek to protect their interests and that of their nationals. Part of this screening is related to state-owned enterprises (SOEs) from developing countries becoming important outward investors, and the fear that their motives are, at least partly, non-commercial in nature (Cuervo-Cazurra, 2018). ${ }^{6}$

The challenge is to develop guidelines and provide criteria that, at least roughly, allow for some predictability for the entry and operations of international investors; ideally such criteria would also allow third parties to identify government actions that are primarily taken for reasons of FDI protectionism. ${ }^{7}$ Screening guidelines and criteria are all the more important, as binding international investment agreements increasingly contain national security exceptions and self-judging essential security interest exceptions that can be evoked by governments to defeat claims concerning actions that otherwise might be considered as violations of investment-treaty protections (such as national treatment, most-favored-nation treatment, and expropriation).

All of this suggests that we can neither take the currently overwhelmingly welcoming national policy regime for granted, nor the strong and open international investment law and policy regime that protects and facilitates such investment. ${ }^{8}$ Indeed, while $95 \%$ of all national FDI policy changes during the 1990s made the regulatory environment more welcoming for foreign investors, ${ }^{9}$ that percentage declined to $78 \%$ during 2010-2019 (UNCTAD, 2020: 97 ${ }^{10}$ ). National policies toward FDI are becoming more nuanced, FDI protectionism is on the rise, and the boundary lines of national security exceptions are expanding. Moreover, new phenomena (such as digital platforms (Srinivasan \& Eden, forthcoming; Stephenson, 2020)) create new challenges and opportunities. The investment regime is evolving and altering the investment landscape and the policy framework for international investors, requiring new responses that need to be formulated within a context characterized by rising "Volatility, Uncertainty, Complexity and Ambiguity" (Buckley, 2020: 1). 


\section{ENCOURAGING SUSTAINABLE FDI}

As a result of COVID-19 and the global recession, global FDI flows in 2020 declined by $42 \%$, from US\$1.5 trillion in 2019 (UNCTAD, 2021b: 1). This is a very steep decline indeed, a decline that could continue into 2021, and one that official development assistance will not compensate.

The implication is that countries, keen to restart their economies, will seek to encourage investment, including by attracting as much FDI as possible. Thus, the world FDI market will become even more competitive. Governments will use all the tools at their disposal to attract and facilitate inward investment. ${ }^{11}$ They are likely to pursue a "the-more-FDI-the-better" approach - and there is some logic to this as, on balance, FDI can make a contribution to economic growth and sustainable development.

At the same time, one should not lose sight of the fact that FDI's economic contribution can be increased by focusing on attracting sustainable FDI (or what the Organisation for Economic Cooperation and Development (OECD) calls "quality FDI" (OECD, 2019)), and making all FDI more sustainable. This requires a focus on actual investment projects, as it is at that level that the impact of FDI in host countries is determined. Thus, "sustainable FDI" involves investments that, "while being commercially viable, involve best efforts toward making a reasonable contribution to the economic, social and environmental development of host countries, and take place in the context of fair governance mechanisms" (Sauvant \& Gabor, 2021: 262). Note that this definition goes beyond doing no harm. ${ }^{12}$ Encouraging sustainable FDI can play an important role in meeting what Zhan (2021) calls the "sustainability endeavor", both in terms of increasing benefits for host countries and meeting the Sustainable Development Goals (SDGs).

The challenge then becomes to identify "sustainable FDI." This can be done by ascertaining "FDI sustainability characteristics," i.e., attributes of investments that suggest that a given project makes a reasonable contribution to development. These sustainability characteristics, in turn, can be gleaned from what governments have identified as contributions they expect from foreign investors; there are plenty of sources in which these are indicated. Having examined a number of these sources, as well as sources in which foreign investors indicate the contributions that they can make, one study shows that there exists, de facto, a consensus between governments and investors as to key FDI sustainability characteristics, resulting in an indicative list of FDI sustainability characteristics (Sauvant \& Mann, 2019). Examples of such characteristics are labor rights, workplace safety, low carbon footprint, supply chain standards, employment, and linkages.

This list is of course preliminary, as it would need to be expanded by examining further sources than were examined in just one study. It is also only indicative, as individual countries have their own priorities regarding the type of contribution they seek from foreign investors. Moreover, there are important questions about trade-offs: while a given investment might score high on, say, workplace safety, it may score low on, say, carbon footprint, and it is also not necessarily sufficient that a given investment is in an SDG sector, e.g., renewable energy or infrastructure, if it scores low on, say, labor rights and linkages.

These are just some of the questions that require further research if one wanted to increase the role that FDI can play in advancing the SDGs. The key is, to re-emphasize, that the focus is - in the framework of appropriate policies, laws and regulations - on individual investment projects, as it is at this level that impact in host countries occurs.

However, the challenge does not end with identifying the quality of FDI. The idea behind the concept of sustainable FDI is not to screen incoming FDI in light of the sustainability characteristics - as mentioned earlier, virtually all investment can make a contribution to development. Rather, the idea is to make special efforts to facilitate FDI projects whose characteristics are most likely to advance countries' sustainable development. This means targeting certain types of FDI. It is an approach that many investment promotion agencies (IPAs) are already pursuing in reference to specific national development objectives they are seeking to advance. All the instruments that they are using for this purpose - from incentives to giving special attention to particular investors - are useful here too.

If we are to achieve the SDGs, further research and evidence-based advice to governments (and especially IPAs) are needed about which instruments can serve the objective of facilitating sustainable FDI, especially now that countries may be less preoccupied with the quality of FDI than its quantity. 
The key is most likely a mixture of encouragement and rewards aimed at enhancing the sustainable FDI characteristics so that projects make a reasonable contribution to sustainable development. An example is the establishment of government-sponsored linkage programs to upgrade local firms to become suppliers to foreign affiliates, considering that backward linkages are one of the most important mechanisms through which domestic firms can benefit from the tangible and intangible assets of foreign affiliates. At the same time, foreign affiliates may well be interested in sourcing locally (if only to protect themselves against supply-chain disruptions), provided costs and quality are satisfactory.

Another approach is to establish the special category of the "Recognized Sustainable Investor." 13 To qualify for such a designation, investors would have to meet certain criteria, e.g., to demonstrate that they have made best efforts toward making a reasonable contribution to enhancing certain sustainability characteristics of their investments and observe their own CSR commitments (focused on environmental, social, and governance impacts), as well as certain widely accepted intergovernmental standards ${ }^{14}$ of responsible business conduct (focused, in addition, on economic development impacts). In return, qualifying investors could benefit from special support by host countries, e.g., certain incentives or dedicated project officers. Acquiring the status of a Recognized Sustainable Investor may be attractive to some investors, especially big ones, for whom the social license to operate is important. Again, however, there are many issues that need to be worked out for such an approach to gain traction. For example, who would decide that investors fulfill the criteria? Who would monitor fulfillment? For how long? Would this need to be projectspecific? How does one avoid that the process becomes a formal "tick-box" exercise, controlled by investors for their own benefit? More research and policy advocacy are required.

\section{ENHANCING THE DISTRIBUTION OF BENEFITS ASSOCIATED WITH FDI: SOME EXAMPLES}

Promoting sustainable FDI, CSR and responsible business conduct represents an across-the-board approach to improving the distribution of economic benefits of FDI as far as host countries are concerned. Beyond this, an important research question is: given the highly competitive world
FDI market, how can host countries maximize the benefits of FDI in concrete policy areas (without, of course, deterring foreign investors)? This is a question worth pursuing not only at the host country level, but also at the level of state contracts between foreign investors and host countries.

\section{State Contracts}

Investment contracts typically govern the exploration and exploitation of minerals and oil, the development of infrastructure ${ }^{15}$ and the acquisition of agricultural land. Such contracts are necessary, as natural resources are generally owned by the state, and infrastructure often requires the taking of land or the granting of monopolies. As the demand for raw materials (as part of the postpandemic recovery) rises, investors seek to acquire land for food production, and the substantial need for infrastructure in developing countries is being addressed, getting these contracts right will become increasingly important. This is so, because such contracts can no longer be easily renegotiated when the situation becomes more favorable to countries. In the past, the bargains struck may have become obsolete, and there is influential literature on this subject (e.g., Vernon, 1971, Ramamurti, 2001, contributions in Grosse, 2011). Today, governments find it increasingly difficult to revise them, given the expansion of guarantees and protections in international investment treaties and their effective enforcement through investorstate dispute settlement. ${ }^{16}$

Arriving at equitable and lasting contracts between foreign investors and host country governments is a considerable challenge for many developing countries. They often involve complex negotiations between sophisticated and well-resourced international investors on the one hand and under-resourced host country governments on the other hand. At the same time, these contracts determine the distribution of benefits between both sides for years to come and often have substantial developmental impacts (Quak, 2018).

For many developing countries - and especially the least - getting these contracts right in terms of structuring them to make investments "sustainable FDI" (and thereby enhancing sustainable development) and viable under future changing circumstances is therefore of key importance. Contract negotiations require a range of experts, including lawyers experienced in the negotiations of such contracts; financial analysts and modelers; environmental experts; and specialists in the 
international markets of, e.g., the minerals covered in contracts.

The problem is that many developing countries do not have the human resources with the required extensive experience to negotiate highly complex contracts effectively. ${ }^{17}$ Often, they also do not have the financial resources to hire international teams of experts to help them negotiate such contracts. International assistance is limited, as multilateral organizations (such as the World Bank) are prevented by key shareholders from providing direct negotiations support, and because such support organizations as CONNEX, the International Senior Lawyers Project and the African Legal Support Facility, ${ }^{18}$ have limited resources.

Research and policy advocacy on how host countries can be assisted in negotiating contracts is, therefore, important. Are model contracts ${ }^{19}$ and/ or detailed negotiations road maps ${ }^{20}$ a way forward and, if yes, under what circumstances? How advantageous is it for governments to take a stake in a given project? What is the scope for backward linkages? Can and should current support organizations be strengthened and, if so, in what manner? These are some of the questions that require further research and policy advocacy to put host countries in a better position to arrive at equitable contracts to benefit adequately from the FDI they receive.

\section{National Policies}

At the host-country level, policy challenges focus on attracting and facilitating FDI and maximizing its benefits. They are plentiful indeed. Several have been addressed in various publications, including in UNCTAD's annual World Investment Reports. To illustrate some of these challenges, three policy areas are highlighted here: dealing with abusive transfer pricing and tax planning, promoting backward linkages, and facilitating outward FDI.

\section{Transfer pricing and tax planning}

It is in the nature of integrated international production systems (UNCTAD, 1993; the "global factory" (Buckley, 2009)) that goods and services are traded across countries - in fact, a substantial share of world trade consists of intra-firm trade among various entities of MNEs (UNCTAD, 1996: 103-104). This raises the question of how to price the goods and services involved for purposes of determining income and thus taxes in the countries involved. The established approach is the arm's-length principle "requiring related-party transactions to be priced as if they had been negotiated between unrelated (arm's-length) parties engaged in the same or similar transactions under the same or similar facts and circumstances" (Eden, 2019: 1). This, of course, leaves considerable latitude to determine prices, especially if no comparable market prices are available; and this, in turn, becomes important if firms want to shift profits from high- to low-tax jurisdictions. It has been estimated that, by using abusive transfer pricing and aggressive tax planning, US $\$ 100$ billion of FDI-related revenues are shifted out of developing countries annually (UNCTAD, 2015: 200) funds that, in many cases, could make an important contribution to advancing sustainable development.

A move toward a global minimum corporate income tax, as foreseen in the OECD's Base Erosion and Profit Shifting initiative, ${ }^{21}$ would alleviate the problem of tax competition to a certain extent by seeking to establish a floor to tax competition. ${ }^{22}$ However, this would still leave room for tax avoidance, especially via the pricing of intangibles and the use of various financing schemes, often linked to tax havens and special-purpose entities. ${ }^{23}$ Many developing countries, in particular, simply are not in a position to deal with sophisticated taxavoidance schemes. Research that determines the various avenues of tax avoidance and develops simple procedures to deal with them would, therefore, be very important; so would be the development of policy recommendations and policy advocacy that translate such recommendations into practice. An example that deserves support is the establishment, by the OECD and the United Nations Development Programme (UNDP), of Tax Inspectors without Borders (OECD, 2020a) and the United Nations Transfer Pricing Manual (United Nations, 2017).

\section{Backward linkages}

As mentioned earlier, backward linkages between foreign affiliates and domestic firms are one of the most effective avenues through which the latter can benefit from the tangible and intangible assets of the former. ${ }^{24} \mathrm{~A}$ few countries have established linkage programs through which governments support the upgrading of domestic firms to make them "linkage ready," i.e., help them reach the standards that international investors expect from their suppliers (and, in the process, embed foreign affiliates more firmly in host countries). In other 
words, strengthening and deepening linkages is a win-win proposition for foreign investors and host countries.

The issue then becomes: how can one encourage the creation and deepening of linkages? International Business scholars, with their understanding of the needs of enterprises, are in an excellent position to identify the obstacles and requirements for linkage-creation and deepening, and the actions firms and governments could take to address them. Such understanding is of particular value at a time of geo-political developments that may lead to a reconfiguration of global value chains. Academic researchers have the skills to advise on government policies that support the creation and deepening of backward linkages and, in this manner, help increase the development impact of FDI.

For instance, would establishing "Linkage Forums" (UNCTAD, 2001: 26) bringing together various stakeholders in public dialogues on linkage creation and deepening be a good starting point? Or multi-stakeholder value-chain partnerships (Findlay \& Hoekman, 2020)? Is linkage creation primarily dependent on the availability of local suppliers that can deliver inputs at the price and quality that are sought by foreign affiliates or are sunk costs and trust in existing supplier relationships more relevant? How can governments build and maintain databases of local enterprises to help investors identify potential subcontractors and ensure that enterprises in the database are linkage-ready through a certification step, so that the databases are trusted and used? What kind of special incentives can be given to foreign affiliates seeking to enhance their sustainability characteristics through the formation or deepening of linkages? How does digitalization impact the development of linkages? Would it make sense to encourage IPAs in developed countries (which increasingly also support outward FDI) to assist IPAs in developing countries in developing linkage programs - perhaps with funds made available in the context of official development assistance, and to help their own outward investors (Stephenson, forthcoming a)? An organization like the World Association of Investment Promotion Agencies could provide the necessary channels to disseminate the results of such research to IPAs worldwide.

\section{Outward FDI}

Traditionally, the lion's share of outward FDI originated in developed countries, and virtually all of them have policies and concrete measures in place to facilitate such investment. These include the provision of information; matchmaking; financial and fiscal incentives; political risk insurance; and the conclusion of international investment agreements that protect outward investors and facilitate their operations (Sauvant et al., 2014).

Today, however, developing countries and economies in transition have become important outward investors as well. They accounted, in 2019, for $30 \%$ of the world's US\$1.3 trillion of FDI outflows (UNCTAD, 2020a: annex Table 1). During 2015-2019, 134 developing countries and economies in transition had outward FDI transactions (UNCTAD, 2020a: annex Table 1). Yet, only a relatively small number of these economies have a clear outward FDI policy and concrete measures in place in reference to their MNEs. The outward FDI policies of developing countries are the neglected twin of their inward FDI policies.

To some extent, this is understandable. The countries involved are focused on attracting FDI to build domestic productive capacity, create employment, and advance their economic development. Intuitively, outward FDI does not help these objectives. Yet, recent research is beginning to show that outward FDI can also benefit home countries that are still developing countries (ESCAP, 2020; Perea \& Stephenson, 2017). The key is that the development of a portfolio of locational assets helps firms to maintain or strengthen their international competitiveness as it provides better access to markets and resources of all kinds - and this, in turn, benefits the wider (home country) economy via positive effects on (among others) economies of scale and productivity of the firms involved; improved accounting, quality, labor, and environmental standards; rising exports; imported technology, innovation, skills, and raw materials; and advancing economic upgrading.

The effect of outward FDI on home-country employment deserves special consideration as it is politically sensitive. While there is a fear that such investment will lead to significant job losses at home, a review of a number of studies suggests that the empirical evidence is more nuanced: in some cases, lower-skilled jobs may be shifted abroad, but the growth of higher-skilled jobs at home often offsets those lost; in addition, these studies have found that outward FDI preserves jobs that would have been lost if firms had not been able to invest abroad (Stephenson, 2018a: 60-68). 
This and many other aspects require further policy-oriented research. For example, is there an optimal sequencing of policies, perhaps along an "OFDI policy path" (Stephenson, forthcoming b) on which governments move from removing restrictions, facilitating outward FDI, promoting it, and calibrating their support in light of their developmental priorities? If so, how can governments determine in which stage they are and what concrete measures are most appropriate for it, given the state of their economies? What are the best institutional arrangements regarding outward FDI: a stand-alone agency? Combining outward and inward FDI promotion? Combining outward FDI activities with export promotion? Or something else? Is there a danger that governments will engage in an outward FDI incentives competition (as they are doing regarding inward FDI) and, if so, how should it be dealt with? Would it make sense to make targeted efforts to increase the channels for outward FDI benefits to flow back to home-country economies and help contribute to sustainable development, e.g., through boosting the capacity of firms to absorb new knowledge, or through incentivizing knowledge diffusion within the home-country economy? (Stephenson, 2018b: 6469; Knoerich, 2017). Finally, how should the concerns of stakeholder groups that are skeptical about outward FDI be addressed?

A toolkit being developed by the United Nations Economic and Social Commission for Asia and the Pacific (ESCAP) and the World Economic Forum in the framework of a workstream that may lead to technical assistance and capacity building may indicate how to move forward on some of these issues (Knoerich, Stephenson \& Taylor-Strauss, forthcoming), but there is plenty of need for more policy-oriented research, recommendations and advice, for the particular benefit of countries with limited capacity in this area.

\section{Transcending the host-/home-country dichotomy}

The question of outward FDI policies draws attention to another aspect related to the distribution of benefits associated with FDI, an aspect that transcends the host-country/home-country dichotomy. Certainly, outward FDI benefits the firms undertaking it, to maintain or enhance their competitiveness. Yet, the more firms that locate assets abroad and internationalize, the more salient the tension pointed out earlier becomes, namely, that governments - of both host and home countries seek to advance their interests within their national contexts, while international investors seek to advance their competitiveness within their international contexts.

The OECD's base-erosion and profit shifting initiative (mentioned earlier) is an indication that both home and host countries are waking up to this issue and seek to address it cooperatively in a multilateral context. Other issues that are likely to be ripe for multilateral attention include mergers and acquisitions (the preferred entry mode of many MNEs) and the associated issues of competition policies, as well as bankruptcy. What other issues are likely to be candidates for a global microregulatory agenda, and how can we address them? (Sauvant, 2016). The only thing that appears to be clear is that the global spread of MNE activities requires a multilateral approach - both to facilitate and regulate these activities.

\section{ANCHORING SUSTAINABLE FDI, CSR, AND RESPONSIBLE BUSINESS CONDUCT IN THE INTERNATIONAL INVESTMENT LAW AND POLICY REGIME}

Strengthening an approach that encourages CSR and responsible business conduct - key aspects of corporate accountability, and one of the major forces identified by Zhan (2021) - would foster sustainable FDI and enhance the distribution of benefits associated with FDI. The contention that enterprises have responsibilities that go beyond shareholders and encompass stakeholders (Milton Friedman not withstanding (Friedman, 1970)), after all, seems to be gaining ground. This is reflected, e.g., in the 2019 US Business Roundtable "Statement on the Purpose of a Corporation." ${ }^{25}$ Accepting a stakeholder approach may be of particular interest to big investors for whom their social license to operate is more under scrutiny than for smaller ones. The challenge is: how to encourage the observance of CSR and responsible business conduct through appropriate policies?

One way in which this can be done is through stronger laws and regulations in individual countries. Examples of countries that have used this approach are India and Egypt. India adopted, in 2013, a CSR law that stipulates that domestic and foreign affiliates in India above certain financial thresholds must spend yearly at least $2 \%$ of their average net profits during the three immediately preceding financial years on specified CSR activities. ${ }^{26}$ Egypt's Investment Law takes a softer approach by providing, in Chapter III ("The social 
responsibility of the investor"): "Toward achieving the goals of the comprehensive and sustainable development, the Investor may dedicate a percentage of his annual profits to create a social development system, outside his Investment Project" (emphasis added) by taking certain listed actions; the amounts spent for these actions "shall not exceed $10 \%$ of his annual profits" (after excluding certain expenses) (Egypt, 2017). Is a compulsory CSR approach (even if soft) - perhaps guided by the SDGs - the way forward if and when firms do not voluntarily implement CSR policies? If so, could it also be applied to foreign affiliates abroad, especially in developing countries? And how could a CSR approach be closely integrated into the very business operations of firms?

However, many individual host countries do not have the strength to effectively adopt, implement, and monitor CSR and responsible business conduct. Another (perhaps complementing) approach involves for individual home countries to require their firms operating abroad to observe certain standards in host countries, an approach that is gaining acceptance. ${ }^{27}$ At the interregional level, this is the approach of the OECD Guidelines - but it is largely voluntary. How to give home countries a greater role in promoting sustainable FDI is an area that requires policy-oriented research.

To avoid the extraterritorial implications of this approach - and to take into account the limited possibilities of many host countries - an international approach would therefore be helpful.

\section{International Investment Agreements}

Of particular interest here is the question of how the concepts of sustainable FDI, CSR, and responsible business conduct can be incorporated in international investment agreements (IIAs). These treaties (primarily some 3000 bilateral investment treaties) constitute the international investment law and policy regime. By design, they facilitate the FDI operations of firms and provide various protections for their foreign investments. Importantly, these treaties are effectively enforced by investors themselves, through the investor-state disputesettlement mechanism provided for in most IIAs. ${ }^{28}$ Again by design, IIAs do not give rights to host countries and responsibilities to foreign investors, making these treaties structurally imbalanced. If the rights of investors are not balanced by responsibilities, the investment regime may lose legitimacy - which may well have implications for FDI flows.
The challenge, thus, becomes: how can IIAs be improved to evolve into instruments that also promote sustainable FDI and investor responsibilities in support of sustainable development? ${ }^{29}$ The renegotiation of existing IIAs and the negotiation of new ones offer opportunities to introduce changes in the traditional approach.

That FDI must contribute to host countries' development is not new in international investment relations. The preambles of a growing number of treaties include specific references to sustainable development (Gordon, Pohl \& Bouchard, 2014), and some IIAs now contain specific provisions in this respect. ${ }^{30}$ This is a beginning. The challenge is to operationalize and firmly anchor this objective in the text of these treaties and their application, so that investment has indeed a substantial sustainable development impact. Options include:

- The Salini criteria, ${ }^{31}$ used to define "investment" for the application of IIAs by arbitral tribunals, can be a starting point. Four of them have gained acceptance: duration, substantial commitment of capital or other resources, expectation of gain or profit, and assumption of risk. The fifth - contribution to the economic development of the host country - has received less attention. ${ }^{32}$ It may be difficult to assess the contribution of a given investment to development. But many other issues that tribunals face are also difficult, e.g., establishing the quantum of awards when tribunals decide in favor of investors. Key is that the preambles of many IIAs specifically provide that they are meant to contribute to development. ${ }^{33}$ Since the FDI sustainability characteristics capture what governments expect from foreign investors and what these investors themselves declare they contribute to host countries, they could be a starting point for assessing the contribution to host countries' development. The widespread acceptance of the Salini criteria would offer an entry point for tribunals that recognize the need for investment to contribute to sustainable development if it is to gain treaty protection.

- IIAs could define "investment" explicitly by reference to the five Salini criteria - clarifying what investments would qualify as sustainable investment.

- IIAs could allow governments to deny protection to investments that fall short of the sustainable investment definition, through a denial-of-benefits clause. 
- IIAs could allow governments to grant preferential treatment to investment that has certain sustainability characteristics (similar to using targeted incentives to invest in renewable energy), permit sustainability exceptions, make sustainability characteristics part of the "like circumstances" analysis for national treatment, ${ }^{34}$ or focus investment facilitation preferentially on such investment (e.g., in reference to Recognized Sustainable Investors). The last approach is particularly relevant, given the WTO's negotiations of an investment facilitation for development agreement (see below).

- Finally, incorporating binding references to CSR and responsible business conduct in IIAs can advance sustainable FDI. ${ }^{35}$ References to such intergovernmental instruments as the UN Guiding Principles on Business and Human Rights, the International Labor Organization (ILO) Tripartite Declaration of Principles Concerning Multinational Enterprises and Social Policy and the OECD Guidelines for Multinational Enterprises would import into investment treaties widely accepted provisions that encourage sustainable investment (relating to, e.g., environmental management, technology transfer, local capacity building). IIAs have begun to do so in their preambles and/or texts. For example, the Comprehensive Economic and Trade Agreement (CETA) Preamble encourages enterprises operating within the territory of the contracting parties or subject to their jurisdiction to respect internationally recognized CSR standards, including the OECD Guidelines. This approach reflects a broader reorientation of IIAs toward recognizing the responsibilities of investors in general and should be encouraged through policy advocacy.

There are certainly more options to anchor the promotion of sustainable FDI in binding IIAs. It is a challenge that is worth pursuing, because these treaties are setting the parameters for domestic investment policy and law-making and because since they are effectively enforced - they can be an important tool to nudge investors in the direction of engaging in best efforts toward making a reasonable contribution to host countries' development.

Again, this requires further research and policy advocacy to move the agenda forward. In the past, developing countries were the main champions of CSR and responsible business conduct in IIAs. Today, scholars - and, for that matter, interested parts of civil society - need to play this role. This is so, because developing countries are becoming less interested in this matter because more and more of their own firms are investing abroad and hence their home-country governments become less interested in imposing obligations on them (while becoming more interested in protecting them).

\section{The WTO Investment Facilitation Framework for Development}

The current WTO negotiations of an Investment Facilitation Framework for Development (IFF4D) offer a concrete opportunity to influence the outcome of a process that may well add an important component to the international investment regime. ${ }^{36}$ This rule-making effort takes place parallel to the discussions and negotiations that are taking place in the framework of UNCITRAL's Working Group III, which focuses on investor-state dispute-settlement reform in IIAs. ${ }^{37}$ (Discussions on improving the investment regime are also being conducted within the framework of UNCTAD and the OECD.) The focus in the present section is on the IFF4D, as the issues addressed in these negotiations are of immediate interest to international business scholars.

The purpose of the WTO negotiations, underway since September 2020 (after several years of preparatory discussions (Gabor, 2021)), is to arrive at a binding multilateral agreement to facilitate flows of FDI for development. They focus entirely on concrete and technical investment-facilitation measures, leaving the controversial issues of market access, investment protection, and investor-state dispute settlement (ISDS) aside (WTO, 2017). Specifically, the negotiations center on four sets of investment-facilitation measures: transparency of investment measures; streamlining and speeding up administrative procedures; focal/enquiry point/ investment facilitator types of mechanisms; and arrangements to enhance domestic coherence and cross-border cooperation on investment facilitation. These technical measures are supplemented by provisions on (among others) the scope of the agreement and general principles; special and differential treatment for developing and least developed countries (including regarding implementation, grace periods, technical assistance, capacity building); cross-cutting issues (including CSR, measures against corruption); and institutional arrangements (including a WTO Committee on Investment Facilitation, exceptions, dispute settlement). ${ }^{38}$ These are all measures to make it 
easier for investors to establish themselves in host countries and operate within them, hopefully thereby increasing FDI flows and advancing economic growth and development.

This approach is, of course, understandable, but it begs the question of whether it might be possible to include in an IFF4D not only measures that facilitate FDI flows, but also measures that directly help to increase the development impact of the investment that host countries receive. One way in which this can be done is to include in an IFF4D a strong reference to CSR and responsible business conduct that requires the signatories of the agreement not only to disseminate internationally recognized standards of such conduct, but also to see to it that these standards are being observed. This could be done by referring explicitly to such standards (especially the above-mentioned UN Guiding Principles, the ILO MNE Declaration and the OECD Guidelines), or by listing key elements of $\mathrm{CSR} /$ responsible business conduct - or by combining both approaches. ${ }^{39}$

A complementary approach would be to include in an agreement concrete measures that focus on facilitating sustainable FDI. For example, it could create the category of the Recognized Sustainable Investor and allow WTO members to let such investors benefit from additional investment-facilitation measures. ${ }^{40}$ The agreement could also encourage, e.g., the establishment of linkage/supplier-development programs in host countries (for the reasons outlined earlier) and the development of marketing strategies targeting sustainable FDI. ${ }^{41}$ It could also require home countries to link their outward FDI support measures to the observation of internationally recognized standards of responsible business conduct. Identifying such measures and including them in an IFF4D is important for an agreement that explicitly is "for Development". It is also important because the implementation of these measures would benefit from any technical assistance commitments that an agreement should stipulate $^{42}$, and the stronger the agreement, the stronger the technical assistance commitments should be.

Given that the negotiations are still ongoing, there is an opportunity to influence them and nudge delegates toward agreeing on a framework that encourages not only more FDI but also more sustainable FDI for sustainable development. Assisting these negotiations by identifying investment facilitation measures - and especially measures that directly increase the development impact of FDI - is important in and by itself. However, it is also important because, if and when these negotiations are successfully concluded, the IFF4D would constitute an influential commitment device, providing a benchmark for governments as to what they are expected to do if they wish to increase FDI flows.

Moreover, and beyond the WTO negotiations, facilitating FDI will become a more important policy challenge as future investment treaties can be expected to include provisions on investment facilitation, as already seen in the Regional Comprehensive Economic Partnership Agreement (Schacherer, 2021). Indeed, separate treaties on this subject will be concluded (e.g., the European Commission is envisaging negotiating an investment-facilitation agreement with Angola). An IFF4D would therefore establish a floor for such provisions and treaties. ${ }^{43}$ Could one develop guiding principles (perhaps endorsed by such an institution as the G20) for the negotiation of bilateral, regional, and multilateral treaty-making efforts on investment facilitation? For instance, could one suggest that such efforts should seek to arrive at a certain balance of measures that facilitate the locational decision-making process for firms (e.g., host countries increasing the transparency of their laws and regulations concerning incoming FDI) and measures that directly contribute more to a host country's development (e.g., MNEs creating linkages)? Or that emphasis is placed on the prevention and management of conflicts between MNEs and host countries and the use of nonadversarial mechanisms (such as mediation) instead of formal dispute-settlement mechanisms (such as ISDS)? Also, learning from the experience of other treaty-making efforts (especially the Trade Facilitation Agreement - Hoekman, 2021), that stakeholder groups should be able to make an input into the negotiations process? This would be important not only to bring in ground-level experience but also to build an informed constituency for the implementation of the resulting treaty (which Hoekman (2021: 16) refers to as mobilizing "a broad 'epistemic community' to establish/agree on what constitutes good practice"). This last point is particularly critical for treaties that are very detailed and therefore depend on practical experience to understand what is doable.

As countries seek to attract sustainable FDI for sustainable development and are negotiating treaties on this subject, they will need to understand how to progress best in this area. International 
business scholars who are experts on MNE operations are in an excellent position to make a contribution toward this effort.

\section{CONCLUSION}

As Zhan (2021) pointed out, the sustainability endeavor and corporate accountability are two major forces re-shaping the FDI landscape. This article sought to operationalize them in the context of the overarching question of the distribution of benefits associated with FDI and, more specifically, how governments can benefit as much as possible from such investment.

In addressing this question, we need to recognize that, for governments, FDI is a tool to advance their national economic growth and development, while taking into account such other objectives as protecting their essential national security interests. Accordingly, governments formulate their national and international FDI policies with their national objectives in mind, while being aware that international investors seek to maintain or increase their competitiveness in an international context. This, in turn, creates a basic tension that needs to be managed. To quote again Vernon (this time from his prescient volume "Sovereignty at Bay" (1971: 284), published more than 25 years before his "In the Hurricane's Eye"): "The basic asymmetry between multinational enterprises and national governments may be tolerable up to a point, but beyond that point there is a need to reestablish balance".

If we want to avoid that this asymmetry becomes intolerable, if international investors are to prosper and countries to benefit from FDI to the greatest extent possible, the challenge is to find ways to reconcile the interests of governments and MNEs with each other, i.e., to arrive at an overlap and balance that makes it interesting for governments to admit FDI into their economies and for investors to invest in them.

It is a delicate balance, and it has to be found increasingly in the context of encouraging sustainable FDI for sustainable development, since sustainable development has become the lodestar of economic policy. If governments' assessment of the impact of FDI, possibly accentuated by non-economic considerations, is unfavorable, it is likely to lead to a deterioration in the relationship between MNEs and governments. The challenge is for governments, in interaction with international investors, to arrive at the appropriate corporate and policy approaches.

During the past 30 years or so, we have witnessed a policy approach that welcomes FDI. It was underpinned by an international investment law and policy regime that protects and facilitates investment flows, enforced through a strong dispute-settlement mechanism. This policy approach is based on the consideration that (non-economic considerations aside) FDI makes a contribution to national development and therefore should be welcomed and encouraged.

We should, however, not take a welcoming national FDI policy approach and a liberal, open international investment regime for granted, nor that countries benefit automatically in a satisfactorily manner from FDI. As any regime, the national and international investment regimes are subject to challenges in light of shifting national preferences and calculations. The investment regime has changed in the past and is in the process of doing so again. While red tape has not replaced red carpet, there is a trend for national (inward and outward) FDI policies to become more nuanced, with this greater nuance being reflected in international investment agreements.

This article has discussed several concrete and actionable policy areas in which the distribution of benefits can be influenced. It has also suggested how this can be done, namely by encouraging more sustainable FDI for sustainable development and enhancing the distribution of benefits associated with FDI in concrete policy areas. These were exemplified by discussing state contracts, transfer pricing and tax planning, backward linkages, and outward FDI; and anchoring sustainable FDI, CSR and responsible business conduct in the international investment law and policy regime and, specifically in the context of the negotiations of a WTO Investment Facilitation Framework for Development.

Influencing the distribution of benefits in favor of countries is not an easy task under any circumstances, given how competitive the world FDI market is. It is even more difficult now, as the world emerges from the COVID-19 crisis and governments will make every effort to restart their economies, including by competing for FDI; but, then, the crisis is also an opportunity to "build back better" (Guterres, 2020).

Scholars from a range of disciplines should undertake applied policy-oriented research, provide policy advice and engage in policy advocacy in the 
FDI space to make sure that countries receive their share of the benefits of FDI. Moreover, dealing with FDI policy challenges requires an interdisciplinary approach, as these challenges concern not just business activities involving a range of issues normally considered by many international business scholars, but they also involve economic and political economy issues of concern to host (and increasingly home) countries. They need to be addressed within the framework of an international investment law and a policy regime that progressively sets the parameters for national law and policy making.

Working with international organizations with FDI work programs, such as UNCTAD, the Word Bank, the United Nations International Trade Centre (ITC), the United Nations Commission on International Trade Law (UNCITRAL), the United Nations Industrial Development Organization (UNIDO), OECD, and the World Association of Investment Promotion Agencies, provides entry points for policy advice and advocacy. Policy makers in individual countries can also be advised on national laws relating to inward and outward FDI, especially relating to corporate social responsibility issues. ${ }^{44}$ Individual IPAs - many of which, especially in most developing countries, are woefully under-resourced - may well be receptive to advice and advocacy as well. And there are various non-governmental organizations that may welcome informed support; some of these are quite specialized, such as Tax Inspectors without Borders, an organization that helps developing countries to increase their tax revenues.

Academics in the international investment law area have shown how this can be done, by establishing the "ISDS Academic Forum" 45 to provide targeted input into the deliberations of UNCITRAL's Working Group III mentioned earlier. The ITC and the German Development Institute have established an "Expert Network" to channel policy advice into the WTO investment-facilitation negotiations. UNCTAD and the OECD organize conferences to which academics are invited, and the OECD even seeks comments through public consultations on policy-oriented papers that it prepares (OECD, 2021). Individual governments, too, provide formal opportunities for academics to make an input into ongoing policy discussions. ${ }^{46}$ Maybe the international business academic community could take a leaf from their colleagues in the international investment law community and find a way to provide policy oriented, evidence-based inputs into various national and international rule-making and discussion endeavors.

After all, international business scholars have the expertise to identify key areas in the interaction between MNEs and governments, design appropriate ways to address them and help translate them into action. They should take the opportunities that exist to do just that.

\section{NOTES}

1 Since 1991 (documented in UNCTAD's World Investment Reports), policy changes have been overwhelmingly in the direction of making the investment climate more welcoming for foreign investors. Moreover, virtually every country has an investment promotion agency, often also sub-national ones. Also, virtually all countries have concluded treaties to protect international investors and facilitate their operations.

2 I am using "CSR" to refer to environmental, social and governance impacts of firms and "responsible business conduct" as referring to the same (CSR) impacts plus their direct and indirect commercial and productive impacts, as captured, for instance, in the OECD Guidelines for Multinational Enterprises (OECD, 2011). (The concepts are frequently used interchangeably.) To quote the OECD (OECD, 2015): "Responsible business conduct (RBC) entails above all compliance with laws, such as those on respecting human rights, environmental protection, labour relations and financial accountability, even where these are poorly enforced. It also involves responding to societal expectations communicated by channels other than the law, e.g., inter-governmental organisations, within the workplace, by local communities and trade unions, or via the press. Private voluntary initiatives addressing this latter aspect of RBC are often referred to as corporate social responsibility (CSR)." The broader concept of responsible business conduct is appropriate for MNEs, as their impact, arguably, is first of all economic; and it is of particular interest to developing countries, as one of their most important aims is economic development and, therefore, directly related to the first SDG, poverty reduction.

3 The same consideration applies also to home countries regarding outward FDI, as witnessed by the approach of the US to outward FDI under the Trump administration. 
4 See in this context also the debate between Reich, 1990; Tyson, 1991; Reich, 1991; Tyson, 2012; Reich, 2015, some 30 years ago but still entirely relevant today.

5 Actually, primarily mergers and acquisitions which, however, account for the bulk of incoming FDI

6 SOEs from developed countries are more important outward investors than those from developing countries, measured by their foreign assets (Sauvant \& Strauss, 2012).

7 The OECD has done considerable work on designing effective and open investment policies that take account of needs to protect essential security interests (see, OECD/natsec), resulting in standard setting (notably the 2009 Guidelines for Recipient Country Investment Policies relating to National Security). However, as Lai (2021) showed, governments deliberately couch national security concerns (not surprisingly) in vague terms.

8 For example, government policies regarding FDI during the 1970 s were highly critical, reflected in the spate of nationalizations that took place especially during the first half of that decade (Kobrin, 1984).

9 UNCTAD, World Investment Reports, various issues.

10 The average of the annual percentage changes during this period.

11 To take a recent example, it has been reported (Kerr \& Andrew 2021) that Saudi Arabia is offering a 50-year tax holiday, waiving quota on the employment of nationals and giving protection guarantees against future regulations to boost FDI inflows.

12 For a discussion of this issue, exemplified by the avoidance and mitigation of human rights risks vs. the promotion of human rights, see Muchlinski, 2012.

13 For an elaboration, see, Sauvant and Gabor, 2021.

14 In particular, the UN Guiding Principles on Business and Human Rights, the ILO Tripartite Declaration of Principles Concerning Multinational Enterprises and Social Policy, and the OECD Guidelines for Multinational Enterprises.

15 It has been estimated that the infrastructure financing gap alone amounts to US $\$ 15$ trillion by 2040 (George et al., 2019).

16 If host countries seek unilaterally to change the terms of contracts, investors typically have access to investor-state dispute settlement that would sanction any contract violations; contrary to the past, contract bargains no longer become obsolete (Sauvant \& Wells, 2021).

17 Indeed, if countries need to negotiate (or renegotiate) large-scale investment contracts only occasionally, it may not be the best use of scarce resources to develop the required expertise locally.

18 See, respectively, https://www.connexintl.com/; https://islp.org/; https://www.aflsf.org/.

19 For an example, see Extractive Hub (2005). Individual countries have developed model contracts over the years. One of the problems with general model contracts is that they pay no attention to the particular legal, economic and political environment of individual host countries or link them to existing agreements. Yet, who drafts a model contract is important: the first mover has a negotiating advantage.

20 The CCSI Negotiations Roadmap is available at: http://negotiationsupport.org/roadmap (last visited January 12, 2021).

21 https://www.oecd.org/tax/beps/, last visited January 12, 2021.

22 As the OECD Secretariat reports, "bank secrecy for tax purposes, and the tax evasion it facilitated, have been seriously reduced" as a result of the cooperation among the 161 members of the OECD-hosted Global Forum on Transparency and Exchange of Information for Tax Purposes (OECD, 2020b: 5).

23 For a discussion, see UNCTAD, 2015, chapter V. A floor to tax competition would, however, not necessarily alleviate abusive practice related to transfer pricing, the structuring of intrafirm debt and possibilities to influence dividend payments when governments own equity in a project.

24 For an extensive recent discussion of the range of issues related to linkages, see, Jordaan, Douw \& Qiang, 2020; UNCTAD, 2010; OECD-UNIDO, 2019b.

25 Available at: https://opportunity.businessround table.org/ourcommitment/, last visited January 12,2021 . But see the critical discussion in Bebchuk \& Tallarita, 2020.

26 The CSR law is contained in Section 135 of the Companies Act, 2013, available at: https://www. mca.gov.in/SearchableActs/Section 135.htm (last visited January 12, 2021). Schedule VII of the Companies Act lists the following areas: eradicating hunger, poverty and malnutrition, sanitation, promoting education, promoting gender equality, ensuring environmental 
stability, protection of national heritage, measures for the benefit of armed forces veterans, and rural development projects; available at: http://ebook.mca.gov.in/Actpagedisplay.aspx?PA GENAME=17923, last visited January 12, 2021.

27 See, e.g., The Foreign Corrupt Practices Act of 1977; see also "Loi Sapin" II, No. 2016-1691, all last visited January 17, 2021.

28 As of July 31, 2020, there were at least 1061 known treaty-based ISDS disputes; see "Investment Dispute Settlement Navigator, available at: https://investmentpolicy.unctad.org/investment -dispute-settlement?utm_source=World+Investm ent+Network+\%28WIN\%29\&utm_campaign=1e 79616ae4-EMAIL_CAMPAIGN_2017_05_18_COPY _02\&utm_medium =email\&utm_term=0_646aa30 cd0-1e79616ae4-70005285, last visited February 25,2021 . To these, one would have to add ISDS disputes based on contracts and national laws.

29 The following paragraphs draw on Sauvant \& Mann 2019.

30 For example, the Morocco-Nigeria BIT and the Pan-African Investment Code approach.

31 Salini Costruttori S.p.A. and Italstrade S.p.A. v. Morocco, ICSID Case No. ARB/OO/4, Decision on Jurisdiction, 23 July 2001, para. 52. For a discussion of the criteria, see, https://jusmundi.com/en/ document/wiki/en-salini-test. There is, however, a question to what extent digital investments can be considered investments covered by IIAs; for a discussion see, Horvath and Klinkmueller, 2019.

32 For a discussion of why some tribunals have rejected the Salini approach and why this may not be a good idea, see Muchlinski, 2021: 721723.

33 Thus, e.g., the 2010 UK-Colombia BIT provides in its preamble: "Recognising the need to promote and protect foreign investments with the aim to stimulate individual business initiative and to foster the economic prosperity of both Contracting Parties;" available at: https:// investmentpolicy.unctad.org/international-inves tment-agreements/treaty-files/3253/download, last visited 11 February 2021.

34 See the Pan-African Investment Code approach.

35 See in this context OECD, 2021.

36 Delegates are negotiating "with a view to achieving a concrete outcome by the $12^{\text {th }}$ WTO Ministerial Conference (MC12), scheduled for next year" (WTO, 2020), i.e., November/December 2021.
37 See, https://uncitral.un.org/en/working_groups/ $3 /$ investor-state (last visited January 12, 2021) for the materials prepared for this effort.

38 See, documents available at https://docs.wto. org/dol2fe/Pages/FE_Search/FE_S_S006.aspx?Meta Collection $=$ WTO\&SymbolList $=\% 22 \mathrm{INF} \% 2 \mathrm{fIFD}$ $\% 2 \mathrm{f}^{*} \% 22 \&$ Serial $=$ \&IssuingDateFrom = \&Issuing DateTo $=\&$ CATTITLE $=\&$ ConcernedCountryList $=\&$ OtherCountryList $=\&$ SubjectList $=\&$ TypeList $=\&$ FullTextHash $=371857150 \&$ ProductList $=\&$ BodyList $=\&$ OrganizationList $=\&$ ArticleList $=\&$ Contents $=\&$ CollectionList $=\&$ RestrictionType Name $=\&$ PostingDateFrom $=\&$ PostingDateTo $=$ $\&$ DerestrictionDateFrom $=\&$ DerestrictionDateTo $=\&$ ReferenceList $=\&$ Language $=$ ENGLISH\&Search Page $=$ FE_S_S001\&ActiveTabIndex $=0 \&$ HSClassificationList $=\&$ ServicesClassificationList $=\&$ EnvironmentClassificationList $=$ \&ICSClassification List $=$ \&ICSClassificationDescList \%3aEnvironmentClassificationDescList \%3aServicesClassificationDescList \%3aHSClassificationDescList = \&lan guageUIChanged $=$ true, last visited January12, 2021, For potential additional measures, see, ITC \& DIE, 2020.

39 WTO members that explicitly support the inclusion a reference to CSR include Argentina, Brazil, the EU, and Japan; the challenge is to include language that requires not only the dissemination of CSR standards, but also their observance. Moreover, a reference to the OECD MNE Guidelines may be difficult for some WTO members to accept, as they are not members of the OECD and therefore may not have subscribed to them.

40 For a suggestion of how such an Article could look like, see Sauvant \& Gabor, 2021. The proposed Article is patterned on Article 7.7 in the Trade Facilitation Agreement, creating the category of the "Authorized Operator". The Trade Facilitation Agreement is available at: https://www.wto.org/english/docs_e/legal_e/tfanov14_e.htm, last visited January 12, 2021.

41 For potential additional measures, including measures directly enhancing the development impact, see Sauvant et al. 2020.

42 For further suggestions of how an IFF4D could be strengthened to support sustainable development, see ITC \& DIE, 2020.

43 Similar to what the WTO TRIPS and TRIMs agreements do regarding, respectively, the protection of intellectual property rights and performance requirements.

44 See the discussion earlier, on CSR and home country measures. 
45 See, https://www.jus.uio.no/pluricourts/english/ projects/leginvest/academic-forum/.

46 In the case of the US, e.g., there is general legal requirement for a "notice and comment period" to allow civil society, business, labor, and other stakeholders to comment on any proposed regulation; see, https://www.justia.com/administr ative-law/rulemaking-writing-agency-regulations/ notice-and-comment/.

\section{REFERENCES}

Bebchuk, L.A., \& Tallarita, R. 2020. The illusory promise of stakeholder governance.

Bhagwati, J. 2004. In Defense of Globalization. New York: Oxford University Press.

Buckley, J. P. 2009. The impact of the global factory on economic development. Journal of World Business, vol. 44: 131-143, http://www.rcmewhu.com/upload/file/20150507/ 20150507210142 3474.pdf.

Buckley, J. P. 2020. The role of international business theory in an uncertain world. In R. van Tulder, A. Verbeke, \& B. Jankowska (Eds.), International business in a VUCA world: The changing role of states and firms. Emerald: Bingley.

Buckley, J. P. 2021. Theory and policy of megatrends in global value chains. Journal of International Business Policy. Forthcoming.

Cornell Law Review, https://papers.ssrn.com/sol3/papers. cfm?abstract id $=3544978$.

Contractor, F. J. 2021. The world economy will need even more globalization in the post-pandemic 2021 decade. Journal of International Business Studies. Forthcoming.

Cuervo-Cazurra, A. 2018. Thanks but no thanks: state-owned multinationals from emerging markets and host country policies. Journal of International Business Policy, 1, 128-156.

Eden, L. 2019. The arm's-length standard is not the problem. Tax Management International Journal, 48, 1.

Egypt Investment Law. 2017. No. 72/2017. https:// investmentpolicy.unctad.org/investment-laws/laws/167/egyptinvestment-law-. Accessed 17 January 2021.

ESCAP. 2020. Outward Foreign Direct Investment and Home Country Sustainable Development. Bangkok: ESCAP. https:// www.unescap.org/publications/studies-trade-investment-andinnovation-no-93-outward-foreign-direct-investment-and. Accessed 26 February 2020.

Extractive Hub. 2005. Model Mining Agreement. https://www. extractiveshub.org/resource/view/id/1559. Accessed 28 January 2021.

Findlay, C., \& Hoekman, B. 2020. Value chain approaches to reducing policy spillovers on international business. Journal of International Business Policy, 20, 1-20.

Friedman, M. 1970. The social responsibility of business is to increase its profits. The New York Times Magazine: 32-34,122126, https://www.nytimes.com/1970/09/13/archives/a-fried man-doctrine-the-social-responsibility-of-business-is-to.html.

Gabor, E. 2021. Keeping "development" in a multilateral framework on investment facilitation for development. Journal of World Investment and Trade, 22, 41-91.

George, A., R-R Kaldany, R-R \& Losavio, J. 2019, The world is facing a $\$ 15$ trillion infrastructure gap by 2040 . Here's how to bridge it. https://www.weforum.org/agenda/2019/04/ infrastructure-gap-heres-how-to-solve-it.

Gordon, K., Pohl J., \& Bouchard, M. 2014. Investment treaty law, sustainable development and responsible business conduct: A fact-finding survey. OECD Working Papers on

\section{ACKNOWLEDGEMENTS}

The author is grateful to Lorraine Eden, Khalil Hamdani, Stephen J. Kobrin, Peter Muchlinski, Ana Novik, Matthew Stephenson, Lou Wells, and two anonymous reviewers for their helpful feedback on an earlier version of this article, and Hetal Doshi and Nancy $\mathrm{N}$. Stephen for their research assistance.

International Investment. Paris: OECD. http://dx.doi.org/10. 1787/5jz0xvgx1zlt-en. Accessed 26 February 2020.

Grosse, R. (Ed.). 2011. International business and government relations in the 21 st century. Cambridge: Cambridge University Press.

Guterres, A. 2020. We are all in this together: Human rights and COVID-19 response and recovery. https://www.un.org/en/ un-coronavirus-communications-team/we-are-all-togetherhuman-rights-and-covid-19-response-and. Accessed 26 February 2020.

Hoekman, B. 2021. From trade to investment facilitation: Parallels and differences. Geneva: ITC. https://www.intracen. org/uploadedFiles/intracenorg/Content/Redesign/Events/Hoek man_investment_facilitation_Dec_2020_revised_clean_version as\%20of\%20Jan\%2022\%20FV.pdf. Accessed 1 March 2021.

Horvath, E., \& Klinkmueller, S. 2019. The concept of "invest-

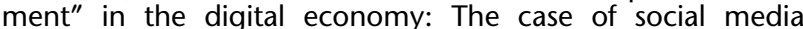
companies. Journal of World Investment and Trade, vol. 20: 577-617, https://brill.com/view/journals/jwit/20/4/articlep577_4.xml.

ITC \& DIE. 2020. What have we learned in the framework of a project on investment facilitation for development: A summary. http://www.intracen.org/itc/Investment-Facilitationfor-Development/. Accessed 12 January 2021.

Jordaan, A. J., Douw W., \& Qiang, C. Z. 2020. Multinational corporation affiliates, backward linkages, and productivity spillovers in developing and emerging economies: Evidence and policy making, Policy Research Working Paper 9364. Washington: World Bank.

Kerr, S., \& Andrew, E. 2021. Saudi Arabia tries to lure multinationals from Dubai. Financial Times. January 11. https://www.ft.com/content/b968a082-486b-4eb0-b268e1f2377891d9. Accessed 17 January 2021.

Knoerich, J. 2017. How does outward foreign direct investment contribute to economic development in less advanced home countries? Oxford Development Studies, 45, 443-459. https:// doi.org/10.1080/13600818.2017.1283009.

Knoerich, J., Stephenson, M., \& Taylor-Strauss, H. OFDI for Sustainable Development Policy Toolkit. Bangkok and Geneva: ESCAP and WEF. Forthcoming.

Kobrin, J. S. 1984. Expropriation as an attempt to control foreign firms in LDCs: Trends from 1960 to 1979. International Studies Quarterly, 28, 329-348.

Lai, K. 2021. National security and FDI policy ambiguity: A commentary. Journal for International Business Policy, 20, 1-10.

Muchlinski, P. 2012. Implementing the new UN corporate human rights framework: implications for corporate law, governance and regulation. Business Ethics Quarterly, 22, 145-177.

Muchlinski, P. T. 2021. Multinational enterprises and the law. Oxford: OUP.

OECD. 2011. Guidelines for multinational enterprises. Paris: OECD. http://www.oecd.org/daf/inv/mne/48004323.pdf. Accessed 26 February 2021. 
OECD. 2015. Policy framework for investment. Paris: OECD. https://www.oecd.org/investment/toolkit/policyareas/respon siblebusinessconduct/. Accessed 25 February 2021.

OECD. 2019. FDI qualities indicators: Measuring the sustainable development impacts of investment. Paris: OECD.

OECD. 2020a. Tax Inspectors Without Borders: supporting developing countries to increase tax revenues despite COVID-19 challenges. https://www.oecd.org/tax/tax-ins pectors-without-borders-supporting-developing-countries-toincrease-tax-revenues-despite-covid-19-challenges.htm. Accessed 12 January 2021.

OECD. 2020b. OECD secretary-general report to G20 finance ministers and Central Bank Governors-July 2020: 5. Paris: OECD. http://www.oecd.org/tax/oecd-secretary-general-taxreport-g20-finance-ministers-July-2020.pdf. Accessed 17 January 2021.

OECD. 2021. Public consultation on business responsibilities and investment treaties. http://www.oecd.org/investment/ public-consultation-on-business-responsibilities-and-investme nt-treaties.htm. Accessed 9 February 2021.

OECD-UNIDO. 2019. Integrating Southeast Asian SMEs in global value chains: Enabling linkages with foreign investors. Paris: OECD, 2019. https://www.oecd.org/fr/investissement/integ rating-southeast-asian-smes-in-global-value-chains.htm. Accessed 9 February 2021.

Perea, J. R. \& Stephenson, M. 2017. Outward FDI from developing countries. In World Bank, global investment competitiveness report 2017/2018: trends and experiences of multinational companies in developing countries: ch. 3 . Washington: World Bank. https://elibrary.worldbank.org/doi/ abs/10.1596/978-1-4648-1175-3_ch. 4. Accessed 17 January 2021.

Quak, E. 2018. The impact of state-investor contracts on development. Brighton: IDS. https://assets.publishing.service.gov. uk/media/5c18dc6a40f0b60c22fb8e88/37. Accessed 11 February 2021.

Ramamurti, R. 2001. The obsolescing "bargaining model"? MNC-host developing country relations revisited. Journal of International Business Studies, 32, 23-39.

Reich, R. 1990. Who is us?. Harvard Business Review. pp. 53-64. https://hbr.org/1990/01/who-is-us. Accessed 17 January 2021.

Reich, R. 1991. Who do we think they are? The American Prospect. pp. 49-53. https://prospect.org/world/rejoinderthink-are/. Accessed 17 January 2021.

Reich, R. 2015. What to do about disloyal corporations? HuffPost Politics. http://www.huffingtonpost.com/robert-reich/whatto-do-about-disloyal_1_b_8734902.html. Accessed 17 January 2021.

Sauvant, K. P., \& Strauss J. 2012. State-controlled entities control nearly US\$ 2 trillion in foreign assets. Columbia FDI Perspectives no. 64, https://ssrn.com/abstract=2896237.

Sauvant, K. P., Persephone E., Ksenia G., Shawn L., \& Witold P. W. 2014. Trends in FDI, home country measures and competitive neutrality. Yearbook on international investment law \& policy 2012-2013: ch.1. New York: OUP. https://papers. ssrn.com/sol3/papers.cfm?abstract_id=2814307 Accessed 12 January 2021.

Sauvant, K.P. 2016. The next step in governance: The need for global micro-regulatory frameworks in the context of expanding international production. In T. C. Ambros, B. Ambros \& J. Birkinshaw (Eds.), Perspectives on headquarters-subsidiary relationships in the contemporary MNC. https://ssrn.com/ abstract=2810355. Accessed 12 January 2021.

Sauvant, K. P. 2019. Promoting sustainable FDI through international investment agreements. Columbia FDI Perspective, no. 251, https://papers.ssrn.com/sol3/papers.cfm?abstract_id= 3383835.

Sauvant, K. P., \& Mann H. 2019. Making FDI more Sustainable: Toward an Indicative List of FDI Sustainability Characteristics. lournal of World Investment and Trade, 20: 916-952, https:// papers.ssrn.com/sol3/papers.cfm?abstract_id=3509771.

Sauvant, K. P., Stephenson M., Hamdani K., \& Kagan Y. 2020. An inventory of concrete measures to facilitate the flow of sustainable FDI: What? Why? How? Geneva \& Bonn: ITC \& DIE. https://ssrn.com/abstract=3739179. Accessed 12 January 2021.

Sauvant, K. P., \& Gabor, E. 2021. Facilitating sustainable FDI for sustainable development in a WTO Investment Facilitation Framework: Four concrete proposals. Journal of World Trade, 55, 261-286.

Sauvant, K.P. \& Wells, L.T. 2021. Obsolescence of the obsolescing bargain: Why governments must get investor-state contracts right. Columbia FDI Perspective, no. 298, https://papers. ssrn.com/sol3/papers.cfm?abstract_id=3787729.

Schacherer, S. 2021. Facilitating investment through IIAs: The case OF THE REGIONAL COMPREHENSIVE ECONOMIC PARTNERSHIP AGREEMENT. Columbia FDI Perspective, no. 295, http://ccsi.columbia.edu/files/2018/10/No-295-Schache rer-FINAL.pdf.

Srinivasan, N. \& Eden L. Going digital multinationals: Navigating economic and social imperatives in a post-pandemic world. Journal of International Business Policy. Forthcoming.

Stephenson, M. 2018a. OFDI roadmap: Creating markets and boosting development through unlocking and leveraging OFDI from developing countries. Geneva: Graduate Institute. https://weforum.ent.box.com/s/v7oi7710t3dse2w19poq9hix yn3tybyt. Accessed 26 February 2021

Stephenson, M. 2018b. Investment as a two-way street: how China used inward and outward investment policy for structural transformation, and how this paradigm can be useful for other emerging economies, PhD dissertation, Graduate Institute of International and Development Studies, Geneva. https://repository.graduateinstitute.ch/record/295767? ln=en. Accessed 12 January 2021.

Stephenson, M. 2020. Digital FDI: Policies, regulations and measures to attract FDI in the digital economy. Geneva: WEF. http://www3.weforum.org/docs/WEF_Digital_FDI_2020.pdf. Accessed 17 January 2021.

Stephenson, M. Forthcoming a. Launching a program for investment partnerships. Columbia FDI Perspective.

Stephenson, M. Forthcoming b. The OFDI policy path and the product space. Columbia FDI Perspective.

Tyson, L. 1991. They are not us: Why American ownership still matters. The American Prospect: 37-48. https://prospect.org/ world/us-american-ownership-still-matters/. Accessed 17 January 2021.

Tyson, L. 2012. Are US multinationals abandoning America? Project Syndicate. https://www.project-syndicate.org/. Accessed 17 January 2021.

UNCTAD. 1993. World investment report 1993: Transnational corporations and integrated international production. Geneva: UNCTAD. https://unctad.org/system/files/official-document/ wir1993 en.pdf. Accessed. 12 January 2021.

UNCTAD. 1996. World investment report 1996: Investment, trade and international policy arrangements: 103-104. Geneva: UNCTAD. https://www.un-ilibrary.org/content/books/97892 13626665. Accessed 17 January 2021.

UNCTAD. 2001. World investment report 2001: Promoting linkages. Geneva: UNCTAD. https://unctad.org/webflyer/ world-investment-report-2001. Accessed 17 January 2021.

UNCTAD. 2010. Creating business linkages: A policy perspective. Geneva: UNCTAD. https://unctad.org/system/files/officialdocument/diaeed20091_en.pdf. Accessed 12 January 2021.

UNCTAD. 2015. World investment report 2015: Reforming international investment governance. Geneva: UNCTAD. https:// unctad.org/system/files/official-document/wir2015_en.pdf. Accessed 12 January 2021.

UNCTAD. 2020. World investment report 2020: International production beyond the pandemic. Geneva: UNCTAD. https:// 
unctad.org/webflyer/world-investment-report-2020. Accessed 17 January 2021.

UNCTAD. 2021a. Investment Policy Monitor. https://unctad.org/ system/files/official-document/diaepcbinf2021d2_en.pdf. Accessed 1 March 2021.

UNCTAD. 2021b. Investment trends monitor. https://unctad.org/ system/files/official-document/diaeiainf2021d1_en.pdf. Accessed 8 February 2021.

United Nations. 2017. Practical manual on transfer pricing for developing countries (2017). New York: United Nations. https ://www.un.org/esa/ffd/wp-content/uploads/2017/04/ Manual-TP-2017.pdf. Accessed 12 January 2021.

Vernon, R. 1971. Sovereignty at Bay: The multinational spread of US enterprises. London: Basic Books.

Vernon, R. 1998. In the Hurricane's eye: The troubled prospects of multinational enterprises. Cambridge, MA.: Harvard University Press.

WTO. 2017. Joint ministerial statement on investment facilitation for development. https://docs.wto.org/dol2fe/Pages/FE Search/FE_S_S009-DP.asp $x$ ?language $=E \&$ CatalogueldList $=$ 240870. Accessed 12 January 2021.
WTO. 2020. Investment facilitation agreement negotiators wrap up productive year. https://www.wto.org/english/news_e/ news20_e/infac_08dec20_e.htm. Accessed 12 January 2021.

Zhan, J. X. 2021. GVC transformation and a new investment landscape in the 2020s: Driving forces, directions, and a forward-looking research and policy agenda. Journal of International Business Policy. https://doi.org/10.1057/s42214-02000088-0.

\section{ABOUT THE AUTHOR}

Karl P. Sauvant is a Resident Senior Fellow at the Columbia Center on Sustainable Investment, a joint center of Columbia Law School and the Earth Institute at Columbia University.

Publisher's Note Springer Nature remains neutral with regard to jurisdictional claims in published maps and institutional affiliations.

Accepted by Sarianna Lundan, Editor-in-Chief, 17 March 2021. This article has been with the authors for one revision and was single-blind reviewed. 